\title{
EVALUATION OF ANALGESIC DRUGS WITH SPECIAL REFERENCE TO SUBJECTIVE RJESPONSES*
}

\author{
E E. DANIEL, PH D.* *
}

\section{INTRODUCTION}

THE EXPERIENCE of pain, like other sensations, is a composite phenomenon. It must involve at least the stimulation of receptors, the transmission of this stimulation to the control nervous system, and the integration of the pain impulses in the CNS with other impulses to produce the response of the organism Clearly, then, there are several places at which one might interfere with the pain experience. One might prevent the stimulation of receptors by avoiding the stimulus or preventing the response of the receptors, or one might interfere with the transmission of pain or its integration at various levels Such measures as local anaesthesia, nerve or cord sections, or frontal lobotomies (9) have been used to remove an unbearable pain experience

Furthermore, as every anaesthetist knows, the total expenience of pain is affected by the past experience and training of the organism Some patients report little or no pain with procedures identical with those producing an unbearable experience in others In a study of unnarcotized wounded in the last war, Beecher et al. (1) could find no correlation between pain and the severity of the wound

Hill and co-workers (15-18) in a sertes of papers have shown that, both in man and in anımals, anxiety over the anticipation of pain is an important part of the pain experience and leads to disruption of organized behaviour. Furthermore, it is well known that emotion can obviate or intensify the reaction to pain For example, Isbell (19) has shown that emotional disturbance of post-addicts at Lexington (produced by unexpected searches etc.) prevented or even reversed in some cases the usual action of morphine on pain threshold

Clearly then, the pain experience may be modified by training or conditioning of the organism in the past or by social or environmental events in the present

Therefore, when one comes to analyse the action of drugs which modify the pain expenience, it is necessary to consider possible effects on many sites: on the pain receptors, on the transmission paths, on the integration of pain with impulses set up by other stimuli at various levels of the central nervous system, on the process of stimulation of other impulses by agents in the internal or external environment, on the past training of the organısm in integrating such sensations

\section{Evaluation of Analgesics using Experimental Pain Thresholds and Proposed Mechanism of Drug Action}

The situation seems to have become confused owing to rigıd adherence to an artificial classification of the possible sites of drug action. Hardy, Wolff and

*Presented at a meetıng of the Western Divisions, Canadian Anaesthetısts' Society, Vancouver, B C, Aprl 5-7, 1956

-Department of Pharmacology, University of Britısh Columbia, Vancouver, B C 
therr co-workers $(13,14,30)$ proposed that analgesic drugs (e.g., acetyl salicylic acid) act primarly by raising the "paun threshold" while others (e.g., opiates) act not only by this mechanism, but also by decreasing pain intensity and by decreasing the "reaction to pain." In the case of opiates, they add "the promotion of sleep" as part of their analgesic action Beecher (3) in studies on clinical pain has emphasized the dichotomy between pain sensation and responses to pain to an even greater degree, though he denies that Hardy ét al (7) have succeeded in separating threshold for sensation from reaction.

When one attempts to give a material meaning to these proposed mechanisms, some difficulties arise. What threshold is elevated-that of the pain receptors, or of some synapse along the transmission path or of some integrating centre? Further, where does the sensation of pan cease and the reaction to pain begin? (In other words, are our reactions to pain, such as reflex withdrawal or muscle spasm or vocalization, a part of the painful experience?) Is there any interaction between the "sensation" and the "response" or the "anticipation"? (Judging from Isbell's work, repeated painful responses lead to anxiety and to alteration in subsequent painful experiences) What ciòes sleep do? Does it rase the pain threshold or alter response to pan? Despite this lack of precision as to the meaning of the dichotomy, Hardy et al (12) have claimed that their radiant heat technique yrelds effects on the sensation of pain more or less independent of the reaction to it Beecher et al. $(2,3)$ on the other hand, believe that their studies on clinical pain are mainly concerned with reaction to pain

To begin to straighten out the existing confusion, it seems necessary to go back and re-examme briefly the experimental evidence on which the separation of the sensation of pain from the response to it was based

Hardy, Wolff and collaborators developed a system using radiant heat to produce repeatable physical changes on the forehead, leading to pain They showed, using themselves as subjects, that a threshold to this pain could be repeatedly determined with minimal variation on the same day There was considerable variation from subject to subject and in the same subject from day to day. However, they found that using a more or less standardized procedure acetyl salicylic acid derivatives raised the "pain threshold" some 30-60 per cent, and that narcotics like morphine could elevate the "threshold" over 100 per cen:.

How did they know that this was a change in the sensation of ratzer than the response to pain? They took as a measure of the reaction to pain, the electrodermal response to the pain (a change in skin resistance) This, in contrast to the pain threshold, they found to be variable and affected by emotional states, fatigue, etc This response was much reduced by opiates, but not by salicylates, even though these also elevated the pain threshold

Several questions immediately come to mind

1. Since the determination of pain threshold was subjective, what role does suggestion play? In other words, what is the response if the subject does not know the nature of the drug? In other studies, conducted by techniques which permit evaluation of the role of suggestion (use of placebos, double blind technique), no consistent elevation of pain thresholds by ASA type analgesics compared to placebos could be demonstrated (26) while elevations produced by opiates $(26,19)$ were much less marked. Subjective responses therefore are 
influenced by suggestions (e g. from takıng of a drug) that pain will be reduced and the occurrence of marked pain relief or elevation of threshold in response to placebos bears this out

Hardy, Wolff and collaborators $(14,32)$ answered this objection by the claim that only trained subjects can determine thresholds and discriminate between drugs and placebos. In our own laboratory, using two different methods of determining pain threshold (deep pain trom a pressure cuff on the lowel leg and periosteal pain by point pressure on the forehead (8)), we have confirmed previous faulures to find consistent differences between drugs and placebo effects on "threshold" with ASA type compounds and found a significant but minor elevation of 15 per cent only in the case of meperidine Furthermore, training of some of the subjects over an enture summer did not improve their ability to discriminate between drug and placebo or did not reduce remarkably the variation from various sources in their threshold determinations Such results leave doubt as to how the relief of pain by drugs clunically in a wide variety of ind1viduals is related to a situation in which change in the pain sensation cannot be consistently demonstrated in the tramed subject. Are we to conclude that the only effect of acetyl salıcylic acid is that of a more or less expensive placebo, or that our methods are as yet madequate? Even in the case of narcotics, where significant elevations over placebo thresholds have been found $(8,26)$, though not invariably (7), there is no proof that the subjects may not have learned to distunguish drug from placebo by some action other than that of pain sensation For example, in our study a large fraction of the students receiving meperidine reported feeling nausea, or drowsiness, or some other drug effect, not reported with ASA compounds or placebos In a careful study of this problem, Lasagna et al (21) have shown that narcotics do produce marked subjective dysphora (not euphoria) in normal healthy individuals. There seems to be a distunct possibility that a subject might learn to recognize mood changes or other effects from opiates and by suggestion and conditioning respond by elevating their pain threshold. Lasagna showed that individuals with such training, post-addicts, could recognize quite small doses of opiates.

2 To what extent is it permissible to compare drug effects in the test situation to conditions under which pain is actually experienced? In most methods of measuring pain threshold, there is no anxiety or fear of conseqrences. The subject knows that the pain will produce no permanent damage, that it is not the harbinger of medical bills or of postoperative complications, and further that it will be over shortly or can be terminated at will Furthermore, as previously mentioned, Hill and co-workers $(18,15)$ have shown that anxiety about anticlpated pain can be conditioned in men and animals and become so strong as to disrupt purposeful behavıou Opiates markedly reduced this response to anticipated pain. These same workers have also shown (17) that painful electric shocks are overestimated when compared to standard shocks by anxious ind1viduals, and that morphine elıminates this effect of anxiety In reassured individuals such errors are not made, and morphine has no effect. Since emotional and environmental factors certainly influence the pain experience, it seems doubtful that results from experimental study can be transferred to clinical pain. 
3. Is the electrodermal response an adequate index of the "response to pain"? Hardy et al. (12) have maintained that prevention of changes in skın resistance after narcotics was evidence of the marked action of narcotics in the "response to pain." Wikler (27) has summarized evidence which casts doubt on this view: the electrodermal response is mankedly affected by barbiturates which are not analgesics, after hypnosis or frontal lobotomy, which relieve pain, various "responses to pain" may be unaffected or intensified. Wikler states (p. 443) "that neither effects on pain threshold, ror effects on measurable physiologic responses to painful stımul are highly relaible indicators of analgesia."

As a result of these divergent results and opinions it is not possible at the present time to give any accurate statement as to the mechanism or site of action of analgesic effects of opiates or other agents such as that proposed by Hardy et al. (30). A useful postulate might be that analgesics interfere with the conditoned responses to anticipated pain and relieve many of the anxueties and responses associated with pain as a result of direct actions on the CNS or on conditioned responses. In any case, it seems unwarranted at this time to dissociate the pain experience into cognition of the sensation and reaction to that cognition, and attempts to do so without recognizing the possibility of their mutual interaction seem to oversimplify the experience

This, of course, rases the question of the validity of all results based on such an attempted dissociation. Wikler. (28) in an attempt to resolve conceptual difficulties stresses the operational approach in which effects of analgesic drugs have meaning only in relation to the method of measurement used. He points out that the process of measurement necessarly involves modification of that which is to be explained for purposes of control and quantification. For example, one must bring the subject into a test situation in either the laboratory or the hospital to evaluate analgesics, but the apparatus or questioning may alter the response of the subject However, Wikler does not diaw what seem the obvious conclusions, namely, that the effects of various factors in the method of evaluation should be studied, and that until such study is complete the most reliable method would be that most closely corresponding to the conditions under which analgesics will be used

\section{Evaluation of A.nalgestcs using Clinical Pain}

With these as well as the previous considerations in mind, Beecher and his group in Boston $(3,25)$ developed a method for the evaluation of analgesics under the actual conditions in whuch most postoperative pain occurs in patients

They have laid down careful methods for guaranteeing that such evaluations will show clearly the pain-reheving effects of drugs under clinical conditions. Their methods involve the adminsstration of drugs to patients and the evaluation by the patient, as well as an objective valuation of their effect in relieving pain The following were features to guarantee correct evaluation.

(a) the use of postoperative patients who fulfilled the following conditions:

(1) had sufficient trauma to warrant persistent postoperative pain,

(2) showed no contra-indications to morphine; 
(3) could give reliable information as to pain relief,

(4) were not in precarious condition, so that there was no risk from placebos, etc.

(b) the use of the double-blind technique in determining drug effects, by which

(1) the placebos were made similar in every possible way to the $\operatorname{drug}(\mathrm{s})$ studied,

(2) neither the patient nor the recording technician knew the agent administered,

(3) neither the patient nor technicians had the opportunity to learn to 1dentify drugs by other effects;

(c) the use of the method of concurrent comparison in which

(1) agents (drugs, placebos) to be compared are given to the same patient, in so far as possible, in order to control variation between patients,

(2) agents to be compared are given in random order so that variation in pain intensity between patients and between various intervals in the same patient can be controlled.

They have used this method extensively to study the curve for the dose effect of sub-cutaneous morphine $(7,25)$ With a placebo, 50 per cent of patients are relieved With $5 \mathrm{mgm}$ of morphine 61 per cent; $8 \mathrm{mgm}$. 74 per cent; $10 \mathrm{mgm}$ 74 per cent, $12 \mathrm{mgm} .71$ per cent; $15 \mathrm{mgm} 83$ per cent In subsequent studies (20) they have not always found the effect of $15 \mathrm{mgm}$. ( $1 / 4$ grain) to be significantly better than that of 8-10 mgm. and present evidence that the higher dose causes more disagreeable side effects, at least in normal indıviduals (Sıde effects cannot be evaluated in postoperative patients because of difficulty in differentiating them from effects of surgery and anaesthesia.) The dose effect curve of morphine requires further study, but results so far indicate that a maximal effect may be achieved at 10-15 mgm of morphine, but that some patients will not be relieved by these doses.

They have been unable to demonstrate any greater effect from oral codeine (60 mgm.) or morphine $(10 \mathrm{mgm}$.) than from a placebo (6) Large doses of acetyl salicylic acid (600 mgm.) did produce slight but significant effects. Elimınation of placebo reactors from the data gave some indication that oral codeme and morphine were analgesic

They have studied the placebo response and report that patients who consistently respond to placebo can be characterized by psychological tests, especially the Rorschach test, and by their reaction to the hospital situation They tended to minimize their pain and when questioned lhought that their care was excellent. They tended to be talkers, to be less educated and more religious. According to the authors, Rorschach tests indicated that placebo reactors were more responsive, anxıous, self-centred and preoccupied with internal body processes, and more emotionally labile. They were more dependent on outside sources of stimulant than on their own mental processes, which were less mature. They had greater instinctual needs and had less developed regulation of the social ex- 
pression of these instincts. They relieved their greater anxiety through their lability and outward orientation (e.g., talking).

However, it should be pointed 'out that there was a larger group of patients who sometimes responded to a placebo. This group also occurred in our own series of medical students. No attempt has yet been made to elucidate the nature of the factors controlling occasional placebo responses.

In line with their findings on the variation in subjective response to placebos, this group has studied the effects of morphine, heroin, amphetamine etc. on mood in normal students, in a group of clinically ill patients. and in post-addicts at Lexington According to their findings it is only in post-addicts that opiates produce euphoria regularly. In the other groups, they most frequently caused dysphoria and unpleasant side effects. A minonty of individuals experienced euphoria, but again these could be characterized by psychological testing as deviants

\section{Practical Implications yor Anaesthesia}

Beecher believes (3) that the effects he finds are primarily on reaction to pain Actually if elevation of pain threshold in experimental studies is made equivalent with pain relief clinically, there is little disagreement as to qualities of drug effect provided only adequately controlled studies are considered. Both studies yield evidence of marked analgesıa independent of suggestion only if opiates and related synthetic drugs are used. The magnitude of the effects seems greater under clinical conditions and some experımental methods do not distinguish them regularly (7) Irrespective of one's opinion as to whether it was the effects of drugs on pain sensation pain response, or on the whole experience which were studied by Beecher's gioup, these results have practical implications.

\section{Postoperative Pain}

1 The dose of morphine Beecher's groups have presented evidence that 8-10 mgm of morphine provides pain reliet equal or nearly equal to that of $15 \mathrm{mgm}$. ( $\mathrm{ca} \%$ grain) of morphine, with a smaller incidence of disagreeable side effects

Tradition has establıshed $1 /$ gram of morphine for the first trial at pain relief. No doubt it is effective in most cases, but would it not be worthwhile to try to determine precisely if equal therapeutic effects can be achieved with a smaller dose? The question requures further study and cannot be answered by dogmatic statement However, if a large number of patients are effectively relieved by 8-10 mgm. of morphine, then there are good reasons for trying it The incidence of addiction is dependent on and drectly related to the total dose injected. The incidence of side effects is similarly related to the dose injected. At the present time it would seem reasonable to try $10 \mathrm{mgm}$ of morphine initially. In most cases, it should be effective.

2. The dose effect curve of morphine. Beecher's group (20) has presented evidence that among postoperative patients there are some who are not relieved by $10 \mathrm{mgm}$ of morphine or any larger dose This raises the practical question: 
Is there a plateau in the dose response curve so that beyond a given dose no further therapeutic effect can be achieved and the possibility of severe depression is enhanced? Clearly this would not completely agree with the old dictum that the dose must be titrated to the patient. The character of the dose effect curve needs further elucidation in patients being treated for pathological pain

3 The placebo reactor Lasagna (22) clams there is such a thing as the small minority of consistent placebo reactors with a definite psychological make-up If so, lackıng a sim sle means of identifying the reactor in advance, there seems to be little possibili $y$ of practical utilization of the fact. If, however, as our data as well as theirs tend to indicate, placebo reaction is an inconsistent response of many individuals to drug therapy, then the environmental factors which tend to promote a favourable placebo reaction should be further studied. Placebo reaction might be used to support the actual theiapeutic effect of drugs if conditions for its occurrence were properly understood

In any case, the fact that placebo reactions do occur should serve as a further reminder that pharmacological effects of drugs per se are not responsible for many of the effects observed in clinical practice. Sir Thomas Lewis (23) has already pointed out that often medical practitioners tend to delude themselves in this regard. He states: "Every student [and he should include us all] should be convinced through both precept and example of the fallacy of the post ergo propter type of argument" "It is unreasonable," he contınues, "that any medical graduate should be ready to believe that any improvement witnessed in a patient under their care is necessarily the result of remedres given. Such men become too easily the dupes of those who trade in proprietary remedies, or of their own too quickly gathering confidence If, atter a remedy is prescribed, one patient improves and another becomes worse, there is on this evidence no more reason to ascribe the first than the second change to the remedy, but exceedingly few qualified men know this"

What placebo reaction implies is that it is not permissible to ascribe automatically the beneficial effects of a remedy to its pharmacological prowess, since suggestion (a placebo) can often produce the same effects The occurrence of marked effects from placebos, especially when subjective effects ale sought, should serve to remind us again that, in every therapeutic effort, the response of the organism is an important, more or less independent element in any effect that may be obtained in the conscious patient The study and rational use of this response may be of great value in the relief of pain or the treatment of disease and certainly will aid in dispelling fath in quacks and their remedies

\section{Pre-Anaesthetic Medication}

Another point that seems to require re-examination is the basis for the use of narcotic analgesics in pre-anaesthetic medication Lasagna (21) has shown that in normal individuals, 1.e not in pain and not post-addicts, morphine, heroin, etc cause dysphoria rather than euphoria What essential role, then, does morphine fill in pre-anaesthetic medication? Beecher (5), on the basis of Lasagna's work, has suggested that nothing desirable is added to pre-anaesthetic medication by morphine, and that there may be a greater risk of $\mathrm{CO}_{2}$ accumulation and other 
effects of its depressant actions He summarizes, but has not yet reported fully, evidence that, using the double blind technique in 558 patients, experienced anaesthetsts could tell when a narcotic had been given with the usual preanaesthetic medication only about 54 per cent of the time. Guessing should have done as well $\mathrm{He}$ also states thrt there is little valid evidence for claims that a pre-anaesthetic narcotic reduces the dose of anaesthetic required to produce a given level of anaesthesia

Certamly this problem requires careful direct exammation by the met ods permitting correct evaluation of subjective effects which have been previously mentioned. However, it does not seem scientfically correct to extrapolate from Lasagna's students to the anxious patient facing operation. Therefore, before any conclusions can be drawn, a study must be made of the effects in such patients of morphine vs. a placebo on the mood, on the ease of induction, on the dose of anaesthetic required for a given plane of anaesthesia, on respiratory exchange in the patient, etc

The work of Hill and co-workers ( 18 ) has already clearly shown that morphine prevents the behaviour-disruping effect of anxiety in post-addıcts. If anxiety does affect any of the significant variables influencing rapidity, ease, and safeness of ảnaesthesia, then moi phine might be expected to remove this effect. Whether the prevention of anxiety by morphine is entirely beneficial or whether it can be provided equally well by adequate sedation with a barbiturate is a question requiring study rather than speculation

\section{ConCLUSION}

Some of our cherished concepts may be modified as our understanding of the mechanisms whereby drugs alter subjective phenomena grows However, cherished concepts are less valuable than the knowledge which permits maximum use of all possible therapeutic tools. We seem to be approaching a day when the study of some drug responses in patients, though difficult, will be widely recognized as necessary, wherever it is possible, because such study provides information which cannot be obtamed in any other way Significantly it is an anaesthetist who is showing that studies in human patients do yield reliable and new information Furthermore, if this field is like others, re-examination of concepts because of their madequacy in practice will have value beyond the immediate range of the practical problems which initiated the reappraisal

\section{RÉSUMÉ}

On a mentionné les endrotts où les drogues peuvent influencer la conduction de la douleur A part l'effet bien connu des drogues sur les récepteurs, sur les voles de transmission, sur l'intégration à différents niveaux, on a insisté sur la possibilité des effets sur le conditionnement antérieur et l'intégration des stimulı environnants.

On a fart chez des humans des études sur la douleur expérımentale, puis devant des conclusions contradictoires et prêtant à confusion, on a repris l'étude du concept voulant que les opiacés agissent en élevant le seırl de la-douleur, en dıminuant les réponses à la douleur et en produisant le sommeil On a mis en 
évidence le rôle de la suggestıon et de l'aptitude à identifier les analgésiques par leurs autres effets pharmacologiques causant une élévation de seuil de la douleur expérimentale. On a cité des expériences où, à l'arde de contrôles personnels, on a démontré que des analgésiques puissants n'avarent que peu ou pas d'effet sur le seul de la douleur. On a pu démontrer, en plus, que les études expérimentales sont incapables de renseigner sur les effets possibles d'une drogue sur l'anxiété et/ou sur plusieurs réponses à une expérience clinique sur la douleur

On a résumé le traval de Beecher, Lasagna et leurs associés de Boston; poun étudier les effets analgésiques, ces auteurs ont employé le soulagement de la douleur clınique, pathologique On a décrit les modes de contrôle employés par ce groupe (les placebos, la technique doublement aveugle, la comparison concomittante, etc.) On a mentionné et discuté quelques-uns de leurs résultats dont les suivants, à savoir.

(a) que la dose optuma pour la morphine est 8-10 mgm. plutôt que $15 \mathrm{mgm}$

(b) que les malades non soulagés par de petites doses de morphne pourraient bien ne pas l'être par de plus fortes doses

(c) que les placebos sont des analgésıques puissants maıs que leur efficacité en cette matière dépend de l'état psychique du patient et de certains autres facteurs inconnus

(d) que les narcotiques pourraient ne jouer aucun rôle essentiel dans la médication préanesthésique

\section{REFERENCES}

1 BeEcher, H K Pain in Men wounded in Battle Ann Surg, 123 96-105 (1946)

2 _._. Expenmental Pharmacology and Measurement of the Subjective Response Science $116 \quad 157-162$ (1952)

3 - Pain Controlled and Uncontrolled Science, 117 166-167 (1953).

4 - - A Method for Quantifyng the Intensity of Pain Science, 118 322-324 (1953)

5 -- Preanesthetic Medication J A M A, 1.57 242-243 (1955)

6 - - Keats, A S, Mosteller, F \& Lasagna, L The Effectiveness of Oral Analgesics (Morphine, Codeine, Acetylsalicylic Acid) and the Problem of Placebo "Reactor" and "Non-Reactors" J Pharmacol \& Exper Therap, 109 S93-400 (1953)

7 Denton, J E \& Beecher, H K New Analgesics I, Methods in the Clinical Evaluation of New Analgesics, II, A Clincal Appraisal of the Narcotic Power of Methadone, and its Isomers. J A.M A , 141 1051-1057 (1949)

8 Foulks, J G \& Daniel, E E To be published (Supported by a grant from Reckitt and Colman (Canada) Ltd)

9 Goetz, F R, Burrill, D Y \& Ivy, A C Critical Evaluation of Algesimetric Methods Quart Bull, Northwestern Uny M School, 17280 (1944)

10 Hammton, F E \& Hayes, G J Prefrontal, Lobotomy in the Management of Intractable Pain Arch Surg, 58 731-738 (1949)

11 Hardy, J D, Wolff, H G. \& Goodeli, H. Studies on Pain A New Method for Measuring Pain Threshold, Observations on Spatial Summation of Pain J Clin Investigation, $19649-657(1940)$

12 Hardy, J D \& Furen, M Reaction to Pain as deternıned by Galvanic Skın Response Federation Proc, 9 56, (1950)

13. Hardy, J D \& Cattell, M Measurement of Pann-Threshold-Raising Action of Aspin, Codeine and Meperidine (Demerol) Federation Proc, 9282 (1950)

14 Harwy, J D., Wolff, H G \& Goodell, H Pain Controlled and Uncontrolled Scince, 117 161-165 (1953) 
15 Hill, Harris E , Beillfyllie, R. E \& Wikler, A Reduction of Pain-Conditioned Anxiety by Analgesıc Doses of Morphine in Rats. Proc Soc Exper Biol. \& Med., 86 881-884 (1954)

16 Hill, H E , Flanary, H G, Kornetsky, C. H. \& Wikler, A. Relationship of Electrically Induced Pain to the Amperage and Wattage of Shock Stımuli J Clin. Investigation, 31 464-472 (1952).

17 Hill, H E., Kornetskx, C H, Flanary, H G \& Wikler, A Effects of Anxiety and Morphine on Discrimmation of Intensities of Pamful Stimuli. J Clin. Investigation, 31. $473-480$ ( 1952)

18 - - Studies on Anxiety associated with Anticipation of Pain 1, Effects of Morphine Arch Neurol \& Psychuat 67 612-619 (1952).

19 Isbell, H Unpublished data Quoted in Wikler, 1950 (see ref. no. 27)

20 Lasagna, L \& Beecher, H. K The Optimal Dose of Morphine J A.M A, 156 230-234 (1954)

21 Lasagna, L, Beecher, H K, \& von Felsinger, J M Drug-induced Mood Changes in Man 1, Observations on Healthy Subjects, Chronically Ill Patients, and "Postaddicts" J A M A , 157 1006-1020 (1955)

22 Lasagna, L, Mosteller, F, von Felsinger, J M, \& Beecher, H K. A Study of the Placebo Response Am J Med, 16 770-779 (1954)

23 Lewis, Sir Thomas Reflections upon Reform-n Medical Education The Lancet, May $30,20,27$ (1944)

24 Keats, A S \& Beecher, H K Pan Relief with Hypnotic Doses of Barbiturates and a Hypothesis J Pharmacol \& Exper Therap, 1001 (1950).

25 Keats, A S, Beecher, H K $\&$ Mosteller, F C Measurement of Pathological Pain in distinction to Expenmental Pam J Appl Physiol, 3. 35-44 (1950).

26 Kunn, R. A \& Brommey, R B Human Pan Thresholds determmed by the Radrant Heat Technique and the Effect upon them of Acetylsalicylic Acid, Morphine Sulfate and Sodium Phenobarbital J Pharmacol \& Exper Therap, 101. 47-55 (1951).

27 Wikler, A. Sites and Mechanisms of Action of Morphme and Related Drugs in the Central Nervous System J Pharmacol \& Exper Therap Part II, 2 (1950)

28 - - Recent Expenmental Studies of Pain and Analgesia Neurol , 3. 656-660 (1953)

29 Wolff, H G On the Nature of Pain. Physiol. Rev, 27 167-199 (1947).

30 - - Hardy, J. D \& Goodell, H Studies on Pain. Measurernent of the Effects of Morphine, Codeine and Other Oplates on the Pain Threshold and an Analysis of Their Relation to the Pain Expenence J Clin. Investigation, 19 659-680 (1941)

31 WoLF, S Effects of Attitude and Conditioning on Action of Chemical Agents in Human Subjects The Pharmacology of Placebos J Clin Investigations, 29 100-109 (1950)

32 WolfF, H G \& Goodels, H The Relation of Attitude and Suggestion to the Perception and Reaction to Paia. Publ Ass. Research Nerv and Ment Dis., 23. 434-448 (1943) 